\title{
Antagonistic activity of glucanolytic bacteria Bacillus subtilis W3.15 against Fusarium oxysporum and its enzyme characterization
}

\author{
RURY ERYNA PUTRI ${ }^{1}$, NISA RACHMANIA MUBARIK ${ }^{2, \boldsymbol{v}}$, LAKSMI AMBARSARI ${ }^{3}$, ARIS TRI WAHYUDI ${ }^{2}$ \\ ${ }^{1}$ Program of Microbiology, Graduate School, Institut Pertanian Bogor. Jl. Raya Dramaga, Kampus IPB Dramaga, Bogor 16680, West Java, Indonesia \\ ${ }^{2}$ Department of Biology, Faculty of Mathematics and Natural Sciences, Institut Pertanian Bogor. J1 Agatis, Kampus IPB Dramaga, Bogor 16680, West \\ Java, Indonesia. Tel./fax.: +62-251-8622833, ^email: nrachmania@apps.ipb.ac.id \\ ${ }^{3}$ Department of Biochemistry, Faculty of Mathematics and Natural Sciences, Institut Pertanian Bogor. J1 Agatis, Kampus IPB Dramaga, Bogor 16680,
} West Java, Indonesia

Manuscript received: 21 July 2021. Revision accepted: 30 August 2021.

\begin{abstract}
Putri RE, Mubarik NR, Ambarsari L, Wahyudi AT. 2021. Antagonistic activity of glucanolytic bacteria Bacillus subtilis W3.15 against Fusarium oxysporum and its enzyme characterization. Biodiversitas 22: 4067-4077. Biocontrol of Fusarium oxysporum, a phytopathogenic fungus that causes plant wilt can be approached with cell-wall degrading enzymes such as $\beta$-glucanase. The aim of this study was to evaluate the prospective ability in glucanase production from several soil bacterial isolates and to characterize its $\beta$ glucanase activity of ammonium sulfate precipitation, and to determine its antifungal activity against $F$. oxysporum in vitro. Twenty bacterial isolates were screened qualitatively and quantitatively as $\beta$-glucanase producers. The results showed that the prospective isolate W3.15 can produce $\beta$-glucanase on glucan agar as the selection medium. From 16S rRNA sequences identification, the isolate belongs to the genus Bacillus, closely related to Bacillus subtilis. The enzyme activity of the ammonium sulfate fraction of isolate W3.15 is optimum at a $\mathrm{pH}$ of 7 and temperature range of $60-80^{\circ} \mathrm{C}$. B. subtilis W3.15 exhibits high inhibition against the mycelial growth of $F$. oxysporum and significantly reduced fungal biomass.
\end{abstract}

Keywords: Ammonium sulfate fraction, Bacillus velezensis, food poisoned assay, fungal biomass

\begin{abstract}
Abbreviations: BLAST: Basic Local Alignment Search Tool; BSA: Bovine Serum Albumin; CBB: Coomassie Brilliant Blue; CMC: carboxymethyl-cellulose; DNA: Deoxyribose Nucleic Acid; DNS: dinitro-salicylic acid, EDTA: ethylenediaminetetraacetic acid; Fox: Fusarium oxysporum; IPBCC: IPB Culture Collection; LB: Luria-Broth; NB: Nutrient Broth; NCBI: National Center of Biotechnology Center; NFW: Nuclease-Free Water; NJ: Neighbor-Joining; PCR: Polymerase Chain Reaction; PDA: Potato Dextrose Agar; PDB: Potato Dextrose Broth; PEG-6000: Polyethylene glycol-6000; rRNA: ribosomal-Ribose Nucleic Acid; SMA: Skim Milk Agar; SPSS: Statistical Packages for the Social Science; TSA: Trypticase Soy Agar
\end{abstract}

\section{INTRODUCTION}

Fusarium oxysporum (Fox), a widely known phytopathogenic fungus is a major threat for many crops and perpetually decreases the crops' yield. Soybean, tomato, banana are experienced annual yield losses due to rot and wilt disease caused by $F$. oxysporum infection (Suárez-Estrella et al. 2007). Management of this pathogen becomes substantial because of the massive damage caused by this fungal infection. For many years, agriculture resisted the $F$. oxysporum infection depending on the chemical treatment. Large quantities of commercial fungicides, such as prochloraz, bromuconazol, propiconazol, and benomyl have been used to control fusarium wilt in the field (Nel et al. 2007; Amini and Dzhalilov 2010). However, the intensive application of these chemical fungicides influenced the accumulation of toxic residues which possibly threaten the agricultural environment (Zhang et al. 2014; Baibakova et al. 2019). It is an urgent issue to develop non-toxic methods such as biocontrol agents or fungal disease management.

Bacteria are commonly used as biocontrol for crops diseases. Bacterial bioactive compounds are widely known for their benefit as biocontrol agents and are non-toxic (Balhara et al. 2011). In particular, cell wall degrading enzymes from bacteria play a role in the biocontrol of fungal diseases along with other bioactive compounds. $\beta$ glucanase can destruct the fungal pathogen cell wall, which contains a large amount of $\beta$-glucan. For Fusarium, $\beta$ glucan and chitin are essential compounds for building fungal cell walls and hyphal propagation (Schoffelmeer et al. 1999). The existence of bacterial $\beta$-glucanase action disrupts the elongation of fungal hyphae and inhibits fungal growth. Hence, $\beta$-glucanase activity may serve as a biocontrol of fungal infection.

Over past years, the Bacilli group produces various microbial bioactive compounds and has been extensively studied for their ability as a biocontrol agent, namely $B$. velezensis, $B$. amyloliquefaciens, $B$. thuringiensis, $B$. subtilis, etc. (Roy et al. 2013; El-Bendary et al. 2016; Jiang et al. 2018; Chun-Hao Jiang et al. 2019). Bacilli spp. produces a resistant endospore to survive in an unfavorable condition, so Bacillus is continuously explored as a biocontrol agent (Chowdhury et al. 2013). Commercial biofertilizers are consist of several strains of beneficial Bacilli that had been confirmed for their antimicrobial and 
plant growth-promoting activities. Previous studies revealed that several Bacillus isolated from soil were potential as biocontrol of fungal wilt in tomato plants due to their ability to inhibit the Fusarium growth in the greenhouse and small-scale field test (Abo-Elyousr and Mohamed 2009; Elanchezhiyan et al. 2018). A study by Dewi et al. (2016) showed that B. subtilis produces $\beta$ glucanase which exhibited strong inhibition against Curvularia affinis and Colletotrichum gleosporioides. Paenibacillus terrae also produces $\beta$-glucanase that protects rice plants from blast disease caused by Magnaporthe oryzae infection (Yu et al. 2019). Therefore, research on fungal cell wall-degrading enzymes as a biocontrol agent in crops protection has become an essential issue.

This paper describes the biocontrol properties of $B$. subtilis W3.15 against the phytopathogenic fungus, Fusarium oxysporum in vitro. Its glucanolytic ability was also evaluated through semi-purification and characterization of $\beta$-glucanase produced by the rhizosphere bacterium Bacillus subtilis W3.15 for enzyme specification and bacterial biocontrol-properties.

\section{MATERIALS AND METHODS}

\section{Microbial Isolates}

Twenty-one isolates from rhizosphere bacteria collection of IPB Culture Collection (IPBCC) were grown on trypticase soy agar (TSA) media and incubated at room temperature $\left( \pm 28{ }^{\circ} \mathrm{C}\right)$ for $24 \mathrm{~h}$. Fusarium oxysporum IPBCC was cultured on Potato Dextrose Agar (PDA) medium at room temperature $\left( \pm 28{ }^{\circ} \mathrm{C}\right)$ under dark conditions for 5 days used in antagonistic in vitro assay.

\section{Screening of beta-glucanase activity}

All of 21 tested bacteria were grown on a selective media enriched with $1 \%(\mathrm{w} / \mathrm{v})$ oat glucan to determine their glucanolytic activity. Single colony of each isolate was inoculated on glucan agar containing $(\%)$ : $\beta$-glucan (1.0), $\mathrm{K}_{2} \mathrm{HPO}_{4}(0.065), \mathrm{KH}_{2} \mathrm{PO}_{4}(0.25),\left(\mathrm{NH}_{4}\right)_{2} \mathrm{SO}_{4}(0.05), \mathrm{NaCl}$ (0.25), $\mathrm{MgSO}_{4} \cdot 7 \mathrm{H}_{2} \mathrm{O}(0.012)$, yeast extract $(0.15)$, and bacto agar (2.0), then incubated at room temperature $( \pm 28$ $\left.{ }^{\circ} \mathrm{C}\right)$ for $48 \mathrm{~h}$. The glucanolytic activity was detected using Congo red solution $0.1 \%(\mathrm{w} / \mathrm{v})$ for 15 minutes then the dye was rinsed with $\mathrm{NaCl} 1 \mathrm{M}$ and repeated three times (Hendricks et al. 1995). A clear zone formed around the colony showed positive glucanolytic activity of the bacterial isolates. The activity was then calculated using the formula of (A-B) $\mathrm{B}^{-1}$, in which $\mathrm{A}$ is the diameter of the clear zone and $\mathrm{B}$ is the diameter of the bacterial colony.

\section{Screening of other hydrolytic enzymes}

To evaluate bacterial ability in producing other hydrolytic enzymes, all bacterial isolates were examined on the assay plates with the different selective media. Cellulase activity was evaluated using carboxymethylcellulose (CMC) medium as described by Asha et al. (2012) with Congo red staining to observe the clear zone. Proteolytic activity was determined using a skim milk agar (SMA) medium containing (per liter): $5 \mathrm{~g}$ pancreatic digest of casein, $2.5 \mathrm{~g}$ yeast extract, $1 \mathrm{~g}$ glucose, $7 \%(\mathrm{w} / \mathrm{v})$ skim milk solution, and $20 \mathrm{~g}$ agar. A clear zone around the bacterial colonies was detected by flooding the plates using Coomassie Brilliant Blue (CBB) solution $(0.25 \% \mathrm{w} / \mathrm{v})$ in methanol: acetic acid: water (5: 1: $4 \mathrm{v} / \mathrm{v})$ for 15 minutes (Khan et al. 2018). Chitin-degrading enzymes were evaluated using $0.3 \%$ (w/v) chitin colloidal media with $0.1 \%$ (w/v) Congo red staining to detect a clear zone around the colony (Mutturi et al. 2020).

\section{Antagonistic activity of bacteria against Fusarium oxysporum}

Qualitative determination of the glucanolytic activity of bacterial cells in inhibiting fungal mycelial growth was performed by the dual culture assay (Haidar et al. 2016). A ten-millimeter plug from the 7-day-old culture of F. oxysporum was inoculated in the center of the PDA medium. The bacterial cell streaked at four equidistant points around the mycelial plug. The assay was performed in triplicate repeated twice. All plates were incubated at $30 \mathrm{oC}$ for 5 days. Mycelial growth was evaluated by measuring the fungal radii from the central fungal plug every $24 \mathrm{~h}$. The equation calculates the percentage of inhibition of bacterial cells against fungal growth:

Percent inhibition $=((\mathrm{R} 1-\mathrm{R} 2) / \mathrm{R}) \times 100 \%$, where $\mathrm{R} 1$ is the mycelium radius toward the bacteria and $R 2$ is the mycelial radius toward the water which is used as a control.

\section{Effect of bacterial culture filtrate on Fusarium oxysporum mycelial growth}

Inhibitory activity of bacterial culture filtrate against fungal mycelial growth was carried out by inoculating a single colony of each isolate into $50 \mathrm{~mL}$ nutrient broth (NB) medium enriched with $1 \%(\mathrm{w} / \mathrm{v})$ oat $\beta$-glucan in 0.05 $\mathrm{M}$ phosphate buffer $\mathrm{pH} \mathrm{7,} \mathrm{and} \mathrm{placed} \mathrm{in} \mathrm{an} \mathrm{orbital} \mathrm{shaker}$ incubator with $120 \mathrm{rpm} 28{ }^{\circ} \mathrm{C}$. After incubation, the bacterial cultures were centrifuged at $4000 \mathrm{xg}$ at $4^{\circ} \mathrm{C}$ for 15 minutes. The supernatant was recovered and filtered using a $0.22 \mu \mathrm{m}$ Millipore filter membrane. About $100 \mu \mathrm{L}$ of filtered supernatant was added to each plate into $15 \mathrm{~mL}$ of PDA medium before solidifying. Sterile water was used as a control. The 10 millimeters plug of 7 day-olds Fox mycelium was placed in the center of the plate (Falcão et al. 2011). Then, the plates were incubated in dark conditions at $28{ }^{\circ} \mathrm{C}$ for 5 days. The experiment was conducted in triplicate with two repetitions and the diameter of Fox's mycelium was measured every day.

The percent inhibition of culture filtrate was calculated using the following equation:

Percent inhibition $=\left(\left(\mathrm{F}_{\text {control }}-\mathrm{F}_{\text {treatment }}\right) \mathrm{F}_{\text {control }}{ }^{-1}\right) \times 100 \%$, where $F_{\text {control }}$ is the diameter of mycelium in the control plate and $F_{\text {treatment }}$ is the diameter of mycelium in the culture filtrate treatment plate. The hyphal alteration was observed under a light microscope (Leica EC4 camera microscope) (Kim et al. 2019).

\section{Effect of co-culture of selected bacteria on Fusarium oxysporum biomass}

Bacterial isolates were co-cultured with fungal mycelia as Dukare et al. (2020) described with minor modifications. 
A single colony of each bacterial isolate (24 hours old culture) was inoculated simultaneously with $F$. oxysporum (cell density $10^{3}$ spores $/ \mathrm{mL}$ ) into a $25 \mathrm{~mL}$ PDB medium. As a control flask, the medium was inoculated with a fungal spore without bacterial culture. All flask was incubated in an orbital shaker at a speed of $120 \mathrm{rpm} 30{ }^{\circ} \mathrm{C}$ in the dark. Fungal biomass was measured at $48 \mathrm{~h}, 72 \mathrm{~h}$, and $96 \mathrm{~h}$ after incubation using Whatman No. 1 filter paper. The experiment was repeated 3 times with 3 replications in each time of observation.

\section{Determination of the optimum production of bacterial $\beta$-glucanase}

One colony of bacteria was inoculated into $20 \mathrm{~mL}$ of NB medium enriched with $1 \%(\mathrm{w} / \mathrm{v})$ oat $\beta$-glucan and incubated overnight in an orbital shaker incubator at 120 $\mathrm{rpm} 28{ }^{\circ} \mathrm{C}\left(\mathrm{OD}_{600}=\sim 0.6\right)$. After overnight incubation, approximately $1 \%$ bacterial inoculum was added into 200 $\mathrm{mL}$ of $\mathrm{NB}$ production medium enriched with $1 \%(\mathrm{w} / \mathrm{v})$ oat $\beta$-glucan diluted in $0.05 \mathrm{M}$ phosphate buffer $\mathrm{pH} 7$. The flask was then placed in an orbital shaker incubator at 120 $\mathrm{rpm} 28{ }^{\circ} \mathrm{C}$ for $48 \mathrm{~h}$. The optical density was measured every $3 \mathrm{~h}$ using a UV-Vis spectrophotometer at $600 \mathrm{~nm}$ (Chasanah et al. 2013). Approximately $5 \mathrm{~mL}$ of bacterial suspension was centrifuged $16000 \mathrm{xg}$ for 15 minutes at $4^{\circ} \mathrm{C}$. The supernatant was recovered for enzyme activity using DNS assay.

\section{Quantitative determination of $\beta$-glucanase activity and protein content}

The culture filtrate of each isolate was tested by dinitrosalicylic acid (DNS) assay, and glucose was used as a standard to measure enzyme activity. The culture filtrate was mixed with $3 \%(\mathrm{w} / \mathrm{v})$ of oat $\beta$-glucan in $0.05 \mathrm{M}$ phosphate buffer $(\mathrm{pH} \mathrm{7})$ then incubated at $50^{\circ} \mathrm{C}$ for 20 minutes (Miller 1959). A total of $2 \mathrm{~mL}$ DNS reagent was added into the sample tube and then boiled for 15 minutes. The absorbance of the solution was measured at $540 \mathrm{~nm}$. One unit of $\beta$-glucanase activity is defined as an amount of enzyme needed to produce $1 \mu \mathrm{mol}$ of glucose at $50^{\circ} \mathrm{C}$ and $\mathrm{pH} 7$. Determination of protein content quantitatively was performed by Bradford macro-assay (Bradford 1976). Bovine serum albumin (BSA) was used as a standard to determine the total protein content in the sample.

\section{Ammonium sulfate precipitation}

Ammonium sulfate was added to the culture filtrate in a certain amount (Senol et al. 2014). A single colony of the bacterial isolate was inoculated into a $20 \mathrm{~mL} \mathrm{NB}$ medium enriched with $1 \%(\mathrm{w} / \mathrm{v})$ oat $\beta$-glucan and incubated in an orbital shaker overnight. Approximately $1 \%$ of bacterial suspension was diluted into a $200 \mathrm{~mL}$ NB production medium and cultured in an orbital shaker incubator at 120 rpm $28{ }^{\circ} \mathrm{C}$ for $21 \mathrm{~h}$. The bacterial suspension was centrifuged at $4000 \mathrm{xg}$ at $4{ }^{\circ} \mathrm{C}$ for 15 minutes. Ammonium sulfate was slowly added into supernatant up to $60 \%$ saturated precipitation (from Simpson Table) in cold condition $\left(10^{\circ} \mathrm{C}\right)$ for $1 \mathrm{~h}$. The suspension was stored at $10^{\circ} \mathrm{C}$ for $24 \mathrm{~h}$ before centrifugated at $16000 \mathrm{xg} 4^{\circ} \mathrm{C}$ for 30 minutes. The precipitate was dissolved in $0.05 \mathrm{M}$ phosphate buffer $\mathrm{pH} 7$ and measured for enzyme activity.

\section{Determination of the optimum pH of bacterial $\beta$ - glucanase}

To determine the optimum $\mathrm{pH}$ value of $\beta$-glucanase from the ammonium sulfate fraction, so the enzyme suspension was tested in three different buffers as previously reported by Kim et al. (2019) with some modifications. The enzyme activity was performed using DNS assay in different $\mathrm{pH}$, in citrate buffer ( $\mathrm{pH} 4-6)$, phosphate buffer ( $\mathrm{pH} 7-8$ ), and glycine-NaOH buffer $(\mathrm{pH}$ $9-10)$. For the substrate, a $3 \%(\mathrm{w} / \mathrm{v})$ oat $\beta$-glucan solution was used in the assay and it was performed in triplicate

\section{Determination of the optimum temperature of bacterial $\beta$-glucanase}

To determine the optimum temperature from the ammonium sulfate fraction of $\beta$-glucanase, the same assay was used as previously described for the determination of the $\mathrm{pH}$ (D.S. Kim et al. 2019). The supernatant was incubated in different temperature ranges from $30-90{ }^{\circ} \mathrm{C}$ using DNS assay. This assay used $3 \%(\mathrm{w} / \mathrm{v})$ oat $\beta$-glucan solution as a substrate and performed three times. Thermal stability was conducted by mixing the supernatant with $3 \%$ (w/v) glucan substrate in $0.05 \mathrm{M}$ phosphate buffer ( $\mathrm{pH} 7$ ) and incubated at the temperature range of $70-80{ }^{\circ} \mathrm{C}$ for $5 \mathrm{~h}$ (interval $1 \mathrm{~h}$ ) (Deng et al. 2010).

\section{Effect of various metal ions and inhibitors on enzyme activity}

The purified enzyme was observed for its enzyme activity in the existence of metal ions and inhibitors. Various metal ions consist of divalent ions $\mathrm{Ca}^{2+}, \mathrm{Mg}^{2+}$, $\mathrm{Fe}^{2+}, \mathrm{Zn}^{2+}$, monovalent ion $\mathrm{Na}^{+}$, and inhibitors of ethylenediaminetetraacetic acid (EDTA) (10 mM) were mixed with pure enzymes in $0.05 \mathrm{M}$ phosphate buffer $\mathrm{pH} 7$. The reaction mixture was tested following the DNS method (Miller 1959). Control treatment used a reaction mixture without the addition of metal ions and inhibitors (Karthik et al. 2015).

\section{Bacterial morphological and molecular identification}

Identification of the morphological characters of bacteria included colony-forming, growth pattern, and Gram-staining as previously described (Wikandari et al. 2012; Khan et al. 2020). The Gram-staining assay for bacterial cells and spores was performed as described previously (Moyes et al. 2009). Biochemical characters were tested as described by Dukare et al. (2020). Molecular identification was carried out on two potential isolates. Two potential isolates were grown in Luria-broth (LB) medium overnight in an orbital shaker at $120 \mathrm{rpm}, 30{ }^{\circ} \mathrm{C}$. The bacterial suspension was centrifuged at $16000 \mathrm{xg}$ for 3 minutes. Bacterial pellets were collected for genome isolation using standard protocols of Presto ${ }^{\mathrm{TM}}$ Mini gDNA Bacteria Kit (Geneaid, Taiwan). A sequence of about 1300 bp of $16 \mathrm{~S}$ rRNA gene was amplified from DNA genome with Biometra $\mathrm{T}$ Gradient Thermoblock PCR Thermocycler (Biometra, Germany), using forward primer 
1387R (5'-GGGCGGWGTGTACAAGGC-3') and 63F (5'CAGGCCTAACACATGCAAGTC-3') (Marchesi et al. 1998). The total volume of PCR reaction used was $50 \mu \mathrm{l}$, contained $25 \mu \mathrm{L}$ kit PCR GoTaq Green Mastermix 2x, $5 \mu \mathrm{L}$ $(10 \mathrm{pmol})$ of both primers, $2 \mu \mathrm{L}$ of DNA genome, and 13 $\mu \mathrm{L}$ of nuclease-free water (NFW). For amplified condition was performed as follows: initial denaturation for 5 minutes at $94{ }^{\circ} \mathrm{C}$, denaturation for 30 seconds at $94{ }^{\circ} \mathrm{C}$, primer annealing for 45 seconds at $54.7^{\circ} \mathrm{C}$, extension for 90 seconds at $72{ }^{\circ} \mathrm{C}$, and final elongation for 10 minutes at $72{ }^{\circ} \mathrm{C}$. Denaturation, primer annealing, and extension were performed for 35 cycles. The PCR product was sent to the sequencing agent. The final sequences were then analyzed using MEGA 6 software for sequence alignment and then BLAST against homologous bacterial 16S rRNA sequences in the NCBI database. The phylogeny trees were constructed based on Neighbor-Joining (NJ) with 1000 bootstrap using MEGA 6 software.

\section{Statistical analysis}

Data of enzyme activity was obtained from three replicates and analyzed using Microsoft Excel 2019 for standard deviation and standard error. Antifungal activity of both isolates was obtained from three replications with three biological replicates and then analyzed using statistical software SPSS version 16.0 by one-way Analysis of Variance (ANOVA). For significance, Duncan's multiple range test was performed on the in vitro data and $p$ $\leq 0.05$ was considered as significant.

\section{RESULTS AND DISCUSSION}

\section{Identification of the potential isolates}

The results of the identification and characterization of the potential isolate were presented in Table 1. Isolate W3.15 formed opaque whitish colonies with raised elevation (Figure 1.A). The edges of the colonies are smooth with a regular circle shape. Isolate W3.15 is Grampositive, rod-shaped, and spore-forming bacteria (Figure
1.B). It showed a centric endospore, with green color in Gram-staining (Figure 1.C). Isolate W3.15 also has positive results for several biochemical assays such as hydrolysis starch, catalase activity, and citrate utilization. The VP test and anaerobic agar also showed positive results on isolate W3.15.

The result on the phylogeny tree analysis showed that isolate W3.15 was closely related to Bacillus subtilis strain MPF73 with 98.8\% similarities, but the bootstrap value of the clade is not strong (68/100) (Figure 2). These three strains lied on a strong branch and clade, indicated from the high bootstraps value to construct the clade (92/100). A clade with high percent similarities (over 95\%) is assumed that the isolates belong to the same species. The gene sequences of 16S rRNA of bacteria W3.15 have been submitted to the GenBank with the accession number MW345907.

Table 1. Morphological and biochemical characteristics of bacterial isolate W3.15 that produce glucanase and antifungal activity

\begin{tabular}{lc}
\hline Characteristics & Isolate W3.15 \\
\hline Colony morphology & round \\
Configurations & smooth \\
Margins & raised \\
Elevation & circular \\
Shape & opaque \\
Pigmentation & \\
Cell morphology & + \\
Gram's reaction & rod \\
Shape & single \\
Arrangement & \\
Biological characteristics & + \\
Catalase & + \\
Voges-Proskauer test & - \\
H2S production & - \\
Urease detected & + \\
Anaerobic agar & + \\
Citrate utilization test & + \\
\hline
\end{tabular}

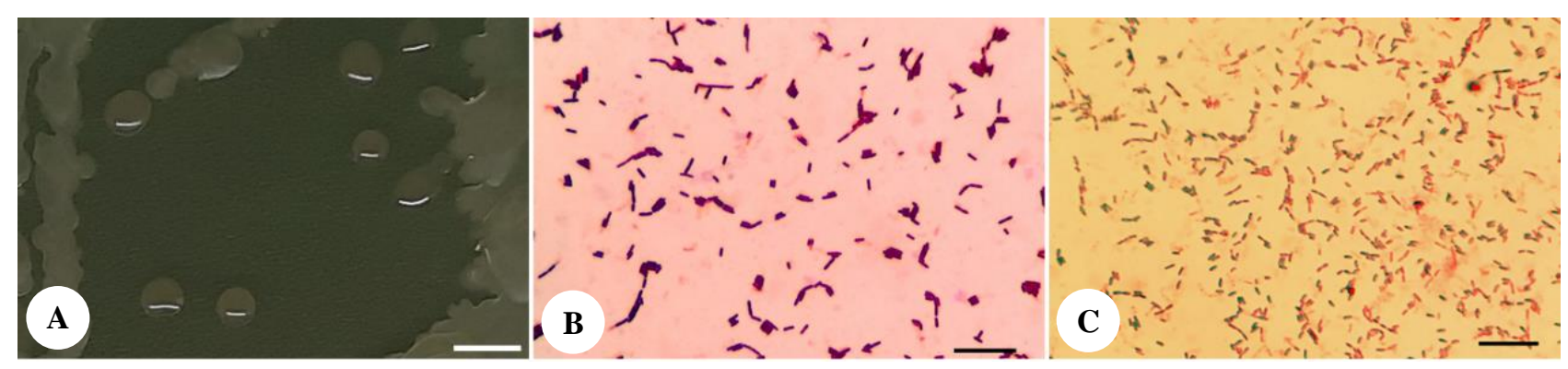

Figure 1. Colony morphology and Gram-staining analysis of cell and endospore of potential isolate W3.15. Isolate W3.15 in TSA medium after $24 \mathrm{~h}$ incubation (A). Gram-positive, rod-shaped cells and endospore of isolate W3.15 (b-c). Bar $0.05 \mathrm{~mm}$ and $0.17 \mathrm{~mm}$. 


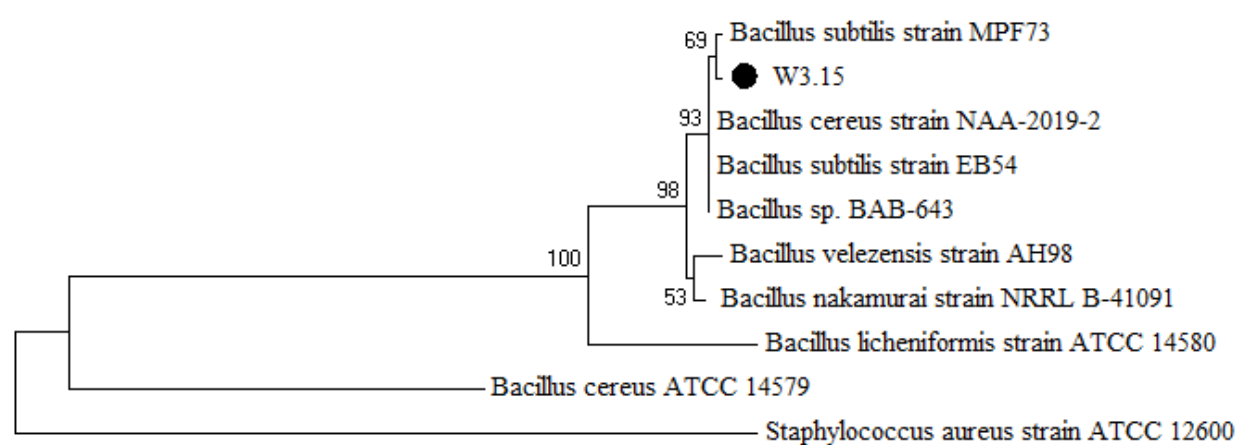

Staphylococcus aureus strain ATCC 12600

0.01

Figure 2. Phylogeny tree analysis of 16S rRNA gene sequences of potential isolate W3.15. Staphylococcus aureus strain ATCC 12600 was used as an outgroup for this analysis

\section{Bacterial ability to produce $\beta$-glucanase}

Screening of all tested bacterial isolates on glucan agar to determine the bacterial ability to produce $\beta$-glucanase. As the positive control, Bacillus velezensis BT2.04 from the previous experiment was used as a positive control to compare the results. The potential isolate W3.15 could break down the oat $\beta$-glucan substrate as indicated by the formation of a clear zone around the bacterial colony (Figure 3.A). The clear zone was formed in 36-42 $\mathrm{h}$ after inoculation at temperature $37^{\circ} \mathrm{C}$. Based on the glucanolytic index value of the bacterial clear zone, it is assumed that W3.15 had a higher glucanolytic ability than other isolates (Table 2). Isolate W3.15 formed a larger clear zone around the colony with a murky appearance (Figure 3.A).

\section{Bacterial ability in hydrolytic enzyme production}

In this study, the potential bacteria was also tested for its ability to produce other hydrolytic enzymes to support the bacterial ability as a biocontrol agent. The results revealed that isolate $\mathrm{W} 3.15$ was able to produce cellulase and protease on the plate assay (Table 2). A clear zone was formed around the colony after the plate was flooded with $0.1 \%$ (w/v) Congo red and $0.25 \%$ (w/v) CBB. However, isolate W3.15 did not the ability to produce chitindegrading enzymes, as was proved by the absence of a clear zone formation around the bacterial colonies after 60 $\mathrm{h}$ of incubation at $30^{\circ} \mathrm{C}$ (Table 3$)$.

\section{Production of $\beta$-glucanase of culture filtrate}

From the enzyme production optimization, the isolate W3.15 was able to grow in the production medium, and the enzyme was produced in addition to substrate oat glucan. The production curve of $\beta$-glucanase compared to bacterial growth showed that $\beta$-glucanase started to be produced within $9 \mathrm{~h}$ after inoculation, at which the cells at an exponential stage (Figure 4). The enzyme was gradually produced until it reached the maximum production peak at $21 \mathrm{~h}$ after inoculation with the specific activity of $\beta$ glucanase of $121.8 \mathrm{U} / \mathrm{mg}$ (Figure 4). Production decreased as the cells entered the stationary phase. After $42 \mathrm{~h}$ of inoculation, there was another peak, but not as high as the first peak with specific activity at $88 \mathrm{U} / \mathrm{mg}$. The second peak indicated the presence of an isoenzyme of $\beta$-glucanase produced by isolate $\mathrm{W} 3.15$.

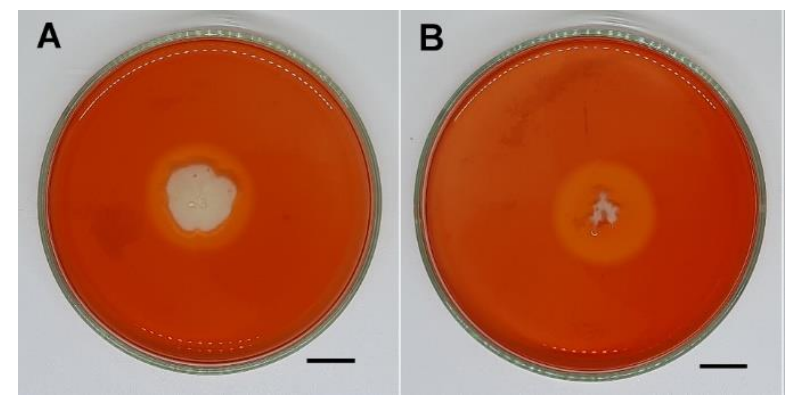

Figure 3. Glucanolytic activity and glucanolytic index value of positive control B. velezensisi BT2.04 (A) and the potential isolate W3.15 (B). The clear zone around the bacterial colony in glucan agar after $48 \mathrm{~h}$ incubation

Table 2. The glucanolytic index derived from bacterial clear zone from several tested bacteria and positive control $B$. velezensis isolate BT2.04

\begin{tabular}{lc}
\hline Isolate code & Glucanolytic index \\
\hline CR. 9 & $5.93 \mathrm{~h}$ \\
W3.15 & $4.94 \mathrm{f}$ \\
W3.1 & $5.29 \mathrm{~g}$ \\
C1.2 & $1.46 \mathrm{~b}$ \\
C2.1 & $1.61 \mathrm{c}$ \\
C3.3 & $2.96 \mathrm{~d}$ \\
PM.2 & $1.09 \mathrm{a}$ \\
BT2.04 & $3.05 \mathrm{e}$ \\
\hline
\end{tabular}

Note: Number followed by the same letter in the same column are not significantly different in the DMRT test $(p \leq 0.05)$

Table 3. The hydrolytic enzyme activity of the potential isolate W3.15

\begin{tabular}{lccc}
\hline Bacterial species & $\begin{array}{c}\text { Cellulase } \\
\text { activity }\end{array}$ & $\begin{array}{c}\text { Protease } \\
\text { activity }\end{array}$ & $\begin{array}{c}\text { Chitinase } \\
\text { activity }\end{array}$ \\
\hline B. subtilis isolate W3.15 & $+^{\mathrm{a}}$ & + & $-{ }^{\mathrm{b}}$ \\
B. velezensis isolate BT2.04 & $\mathrm{n}^{\mathrm{c}}$ & + & - \\
Escherichia coli & - & - & - \\
\hline Note: ${ }^{\mathrm{a}, \mathrm{b}}$ B. velezensis $\mathrm{BT} 2.04$ and $E$. coli were used as positive \\
and negative control, respectively. ${ }^{\mathrm{c}}$ n.t $=$ not tested
\end{tabular}




\section{Characteristics of the purified enzyme}

The enzyme was purified with a $60 \%$ (w/v) saturated ammonium sulfate. The specific activity of the ammonium sulfate fraction of isolate W3.15 was obtained at 279.172 U/mg (Table 4). The ammonium sulfate fraction that was purified up to 1.45-fold had an overall yield of $23.6 \%$. Compared with the culture filtrate activity, the purified enzyme using ammonium sulfate had greater specific activity and total protein reduction. The enzyme activity of the second step of purification using polyethylene glycol 6000 (PEG 6000) was also measured. Overall parameters of enzyme purification obtained from the PEG dialysis showed no significant difference in value compared to ammonium sulfate precipitation (Table 4).

\section{Effect of pH and temperature on activity and stability of $\beta$-glucanase}

In this study, various buffers with different ranges of $\mathrm{pH}$ were tested to determine the optimum $\mathrm{pH}$ for the enzyme activity of isolate W3.15, such as citrate buffer $(\mathrm{pH}$ 4-6), phosphate buffer ( $\mathrm{pH} 7-8$ ), and glycine-NaOH buffer (pH 9-10). As a result, the enzyme activity derived from ammonium sulfate purification of isolate W3.15 showed a peak at pH 7.0 (Figure 5). The optimum $\mathrm{pH}$ value of enzyme activity for isolate $\mathrm{W} 3.15$ was at $\mathrm{pH} 7.0$, and the activity was observed to be stable from pH 6-8 (Figure 5). Enzyme activity decreased at higher $\mathrm{pH}$ values (above 8).

The purified enzyme was also tested in different temperatures to obtain the optimum temperature for enzyme activity. The optimum temperature for the $\beta$ glucanase activity of isolate W3.15 was obtained in the range of $60-80^{\circ} \mathrm{C}$ (Figure 5). In contrast, it was showed that the enzyme activity of isolate $\mathrm{W} 3.15$ retains the activity at a range of $50-70{ }^{\circ} \mathrm{C}$ before elevated at temperature $80^{\circ} \mathrm{C}$ (Figure 5). The higher temperature reduced the enzyme activity in a lower value.

\section{Effect of various metal ions and inhibitors on enzyme activity}

The effect of metal ions addition and EDTA inhibitor on the $\beta$-glucanase activity was presented in Figure 6 . The addition of divalent ions $\mathrm{Ca}^{2+}$ resulted in the highest enzyme activity $(26.8 \%)$ compared to the addition of other metal ions and control (Figure 6). $\mathrm{Ca}^{2+}$ ion could increase enzyme activity up to $2 \%$ compared to the enzyme activity in the control treatment. The addition of $\mathrm{Mg}^{2+}$ also results in high enzyme activity, while the addition of $\mathrm{Na}^{+}$showed the lowest enzyme activity (5.5\%) compared to the addition of other metal ions. The enzyme activity in the treatment of the $\mathrm{Na}^{+}$addition did not differ from EDTA inhibitor treatment (Figure 6).

Table 4. Purification steps of $\beta$-glucanase enzyme produced by isolate W3.15

\begin{tabular}{|c|c|c|c|c|c|c|}
\hline Purification steps & $\begin{array}{c}\text { Volume } \\
(\mathrm{mL})\end{array}$ & $\begin{array}{c}\text { Total protein } \\
\text { amount }(\mathrm{mg} / \mathbf{m L})\end{array}$ & $\begin{array}{c}\text { Total activity } \\
\text { (unit) }\end{array}$ & $\begin{array}{l}\text { Specific activity } \\
\text { (U/mg protein) }\end{array}$ & $\begin{array}{c}\text { Purification } \\
\text { (fold) }\end{array}$ & Yield (\%) \\
\hline Culture filtrate & 50 & 13.21 & 2553.82 & 193.325 & 1 & 100 \\
\hline $\begin{array}{l}\text { Ammonium sulfate } \\
\text { (60\% saturation) }\end{array}$ & 5 & 2.16 & 603.012 & 279.172 & 1.45 & 23.6 \\
\hline PEG dialysis & 10 & 2.08 & 599.713 & 288.324 & 1.49 & 23.5 \\
\hline
\end{tabular}

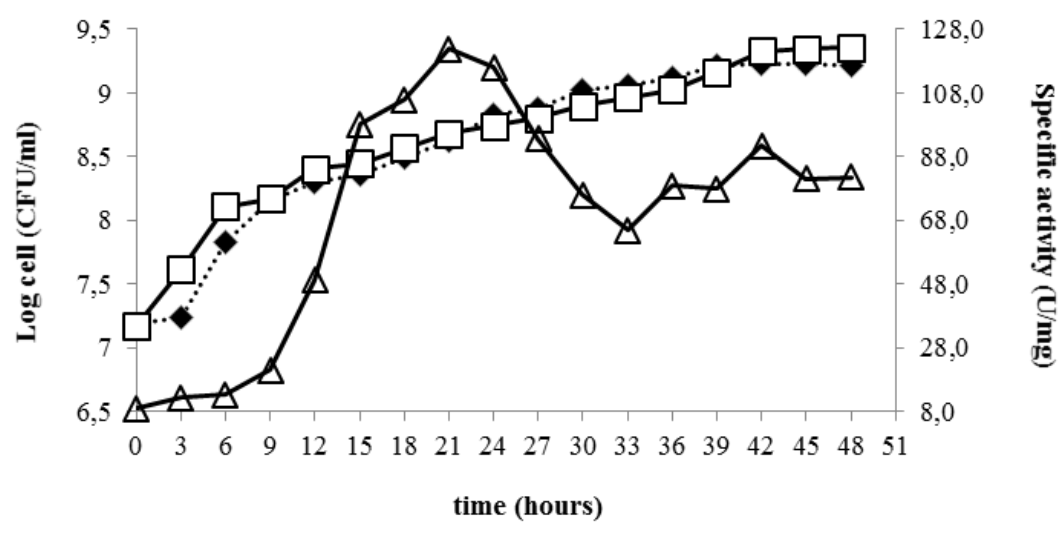

Figure 4. Bacterial cell growth and production curve of isolate W3.15 cultured on two different culture media for $48 \mathrm{~h}$. Cell growth curve of W3.15 on NB medium (line with white inner square); on NB enriched with $1 \%$ oat glucan medium (line with black inner square); enzyme-specific activity values (line with the white inner triangle) at $48 \mathrm{~h}$. 


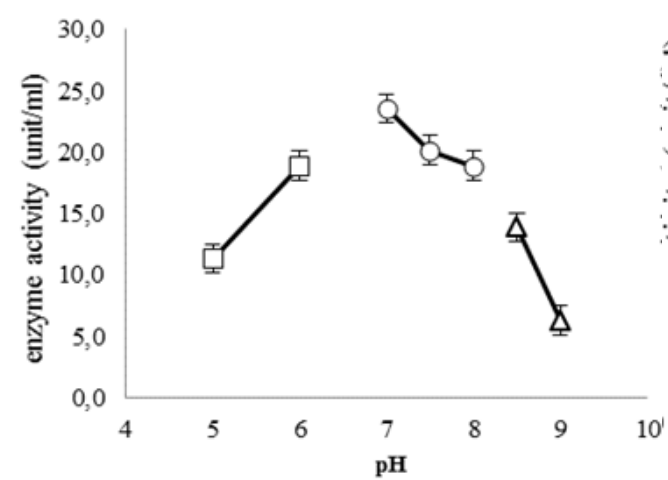

A

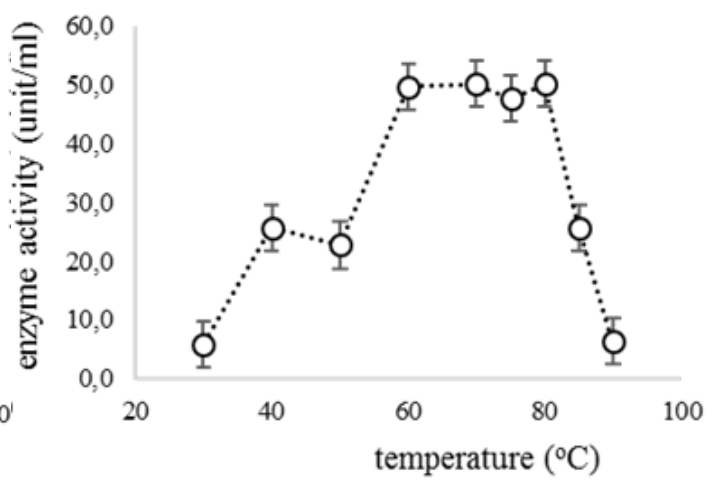

B

Figure 5. Effect of $\mathrm{pH}$ and temperature on the glucanolytic activity of isolate W3.15. Enzyme activity in various buffers with different ranges of $\mathrm{pH}$ value (citrate (square), phosphate (round), glycine- $\mathrm{NaOH}$ (triangle)) (A), and different ranges of incubation temperature (round) (B).

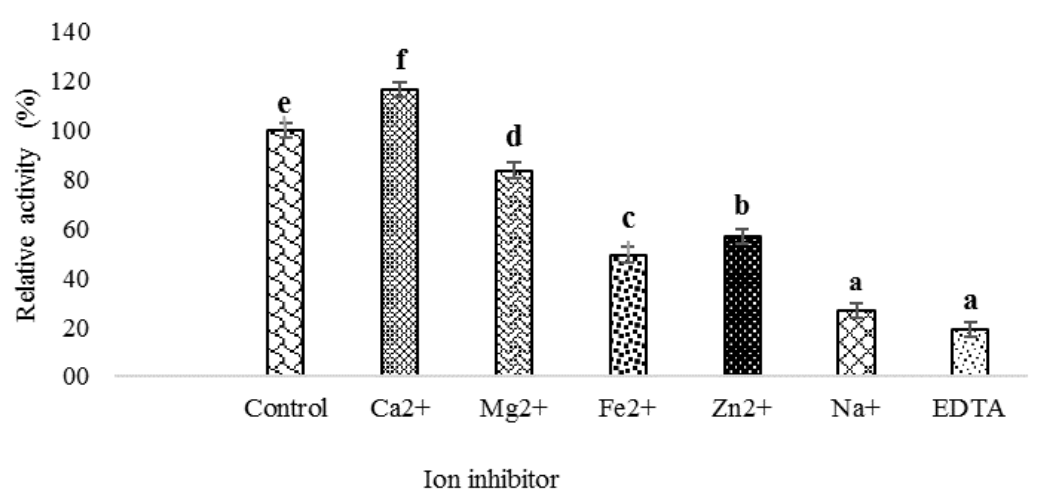

Figure 6. Effect of the addition of various metal ions and inhibitors on the $\beta$-glucanase activity of isolate W3.15. The addition of divalent ions $\mathrm{Ca}^{2+}$ resulted in the highest enzyme activity compared to other divalent ions $\mathrm{Mg}^{2+}, \mathrm{Fe}^{2+}$, and $\mathrm{Zn}^{2+}(p \leq 0.05)$

\section{Antifungal activity of bacterial cell and supernatant against $\boldsymbol{F}$. oxysporum}

The results on a dual culture assay showed that isolate W3.15 inhibited $58.8 \%$ of the growth of $F$. oxysporum mycelium in 6 days observation (Figure 7). The antifungal activity of bacterial metabolites was evaluated by adding $300 \mu \mathrm{l}$ of culture filtrate of isolate W3.15 into the PDA medium. The results showed that the addition of $300 \mu \mathrm{l}$ of culture filtrate of isolate W3.15 inhibited the growth of $F$. oxysporum by $66.5 \%$ inhibition in 6 days of incubation (Figure 7). Moreover, the color of fungal mycelium treated with culture filtrate was a dense pink-whitish mycelial colony, while the color of fungal mycelium in control was a sheer pink-violet colony (Figure 7).

The antifungal activity of bacterial isolate W3.15 can also be observed in the presence of morphological changes or abnormalities of the hyphae. Microscopic observations showed that the dual culture assay and the food poisoned assay resulted in hyphal abnormalities (Figure 8), i.e., a diminution of hyphal diameter followed by distorted and small hyphal branches. The addition of culture filtrate also causes granulation of the hyphal intracellular, some sections formed vacuole along the hyphae (Figure 8).

\section{Effect of co-culture of selected bacteria on fungal biomass}

The antifungal activity of the potential bacteria against $F$. oxysporum growth can also be observed by its ability in reducing fungal biomass. Fungal biomass was estimated from fungal mycelial dry weight over several days of incubation. As a result, B. subtilis isolate W3.15 significantly reduced fungal biomass by up to $70 \%$ compared to control. 

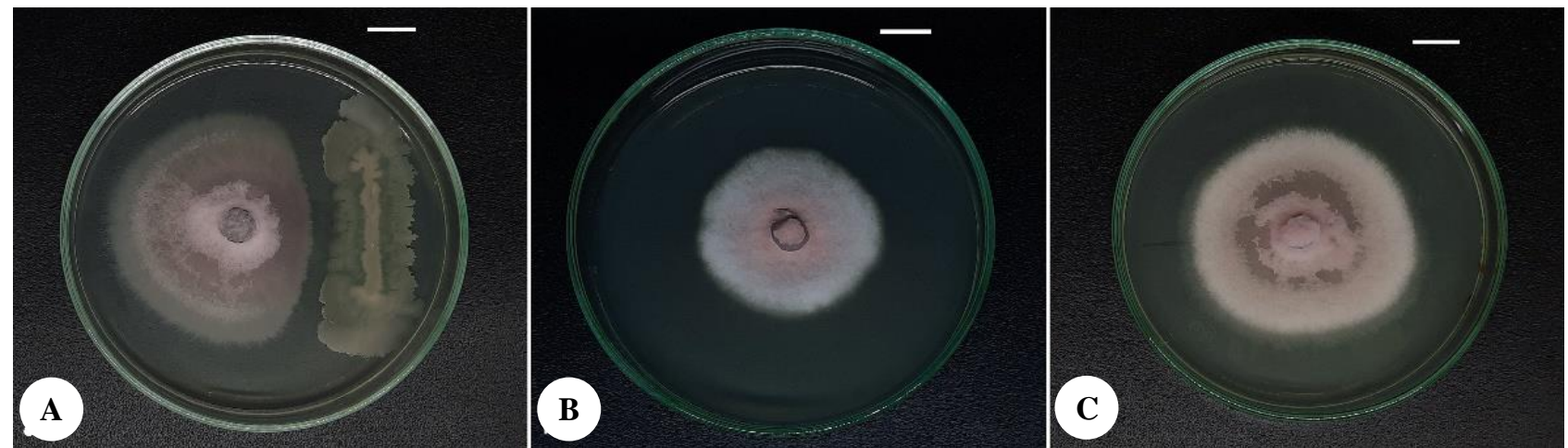

Figure 7. In vitro antifungal activity of bacterial cells and culture filtrate against $F$. oxysporum. Dual culture assay of isolates W3.15 (A) and food poisoned assay of culture filtrate $(300 \mu \mathrm{l})$ of isolate W3.15 (B) compared to the growth of $F$. oxysporum in 6 days old culture (C).

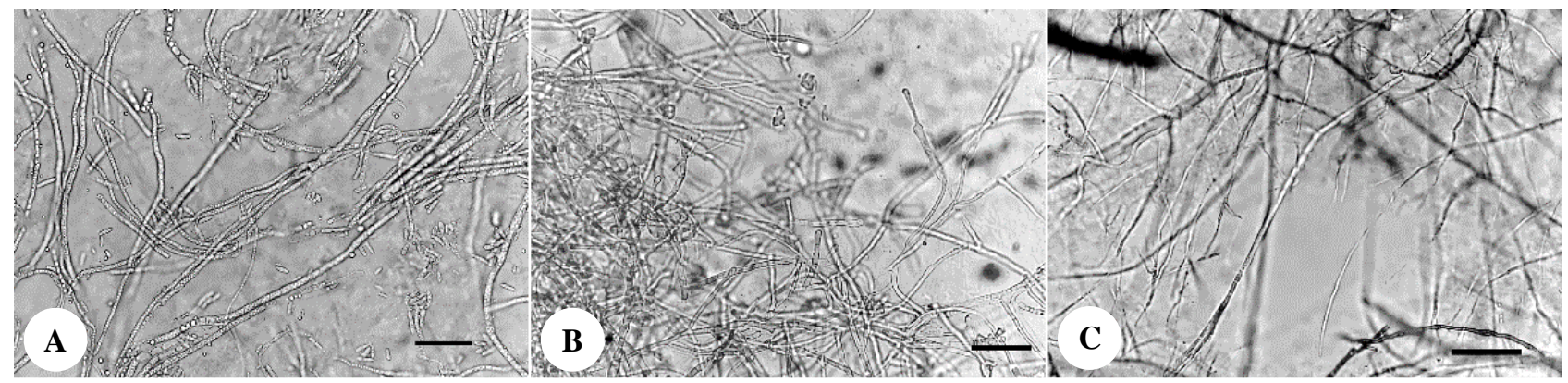

Figure 8. Changes of hyphae morphology in the presence of the bacterial cells and bacterial culture filtrate in 6 days incubation. Normal mycelia of Fusarium oxysporum (A), mycelia with short and irregular branching on the antagonistic treatment of the isolate W3.15 (B), hyphae showing the formation of granules or vacuoles along the hyphae, hyphae deformation, and hyphae death on the addition of culture filtrate $(\mathrm{C})$.

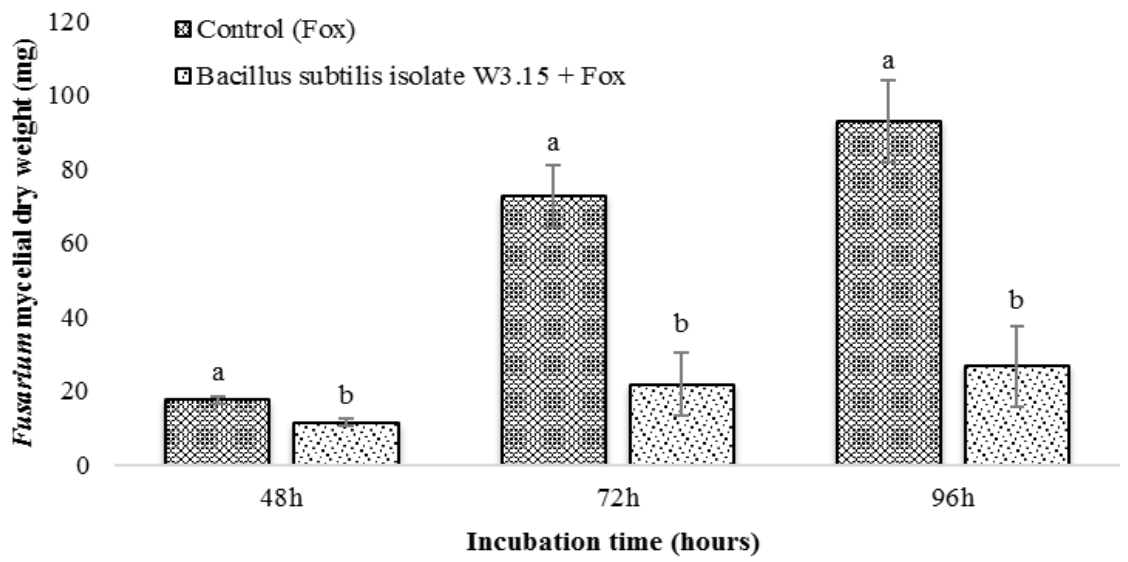

Figure 9. Fungal biomass reduction in the co-culture treatment of B. subtilis W3.15 on simultaneous incubation time (48-96 h) compared to non-treatment (control) biomass $(p \leq 0.05)$

\section{Discussion}

Rhizosphere bacteria are widely known for their ability to produce various natural compounds that can be used as biocontrol of crop diseases. In recent years, natural microorganisms have been extensively studied for fungal disease management to reduce the application of synthetic fungicides. The long-term use of synthetic fungicides harms the health of the agricultural community, including water systems and humans. Biocontrol of pathogenic fungi can be approached by using cell wall degrading enzymes from several groups of soil bacteria. Several isolates of rhizosphere bacteria that have glucanolytic activity had 
been assessed for their ability to inhibit the pathogenic fungus that causes plant wilt, $F$. oxysporum. The potential isolate W3.15 was identified as Bacillus group based on morphological characters and phylogenetically based on $16 \mathrm{~S}$ rRNA sequence. Rhizosphere bacteria B. subtilis is commonly studied for their strong antifungal activity against a wide range of phytopathogenic fungi such as Rhizoctonia solani, Alternaria alternata, F. oxysporum, Macrophomina phaseolina, and Pythium ultimum (Alamri et al. 2012; Wu et al. 2019). B. subtilis suppressed significantly early blight (EB) disease caused by Alternaria solani in tomato plants (Awan and Shoaib 2019). The application of $B$. subtilis as a biocontrol agent can also increase plant growth. Another member of the Bacilli group reported to function as a biocontrol against phytopathogenic fungi in crops is B. velezensis. This study used B. velezensis BT2.04 as a positive control. A previous study showed that B. velezensis RB.DS29 isolated from black pepper (Piper nigrum L.) could significantly inhibit Phytophthora in vitro and reduce disease rates under greenhouse conditions (Trinh et al. 2019). Research by Khan et al. (2020) revealed that the endophytic $B$. velezensis Lle-9 isolated from Lilium leucanthum had a plant growth-promoting effect and antifungal activity against Botrytis cinerea, Fusarium oxysporum, Fusarium fujikuroi, and Botryosphaeria dothidea.

Various bacterial compounds as biocontrol for fungal diseases in crops were reported to strongly inhibit fungal mycelial growth in in-vitro assay or suppress disease rates in the in-vivo experiment. The hydrolytic enzymes from bacteria have been used to break down the hyphal cell wall result in impairing the mycelial growth of phytopathogenic fungi. As a lytic enzyme, $\beta$-glucanase was reported to inhibit the growth of several phytopathogenic fungi in several substantial crops such as tomatoes, lettuce, and potatoes (Alamri et al. 2012). The highlight of this experiment is the potential isolate of B. subtilis strain W3.15 can produce $\beta$-glucanase as a biocontrol candidate for managing $F$. oxysporum infection. Bacillus subtilis W3.15 also produced other hydrolytic enzymes that can inhibit fungal growth, namely protease but it did not produce chitinase. Chitinase is often reported to be able to inhibit several phytopathogenic fungi. Bacillus thuringiensis and $B$. licheniformis are exhibited high chitinase activity which can inhibit $R$. solani, $F$. oxysporum, and Penicillium chrysogenum infection and could increase the germination of soybean seed (Gomaa 2012). From the above results, it was suggested that the antifungal activity of isolates W3.15 is mostly influenced by $\beta$-glucanase and protease.

In this study, oat $\beta$-glucan was supplemented into a medium to induce $\beta$-glucanase production by isolate W3.15. A Supplementation of $3 \%$ oat $\beta$-glucan was used as the main substrate and growth for isolate W3.15 which was indicated by the increase of $\beta$-glucanase activity on the exponential growth of bacteria. As the main metabolite, $\beta$ glucanase produced by $B$. subtilis W3.15 reached its maximum production at $21 \mathrm{~h}$ after inoculation and then decreased in the stationary growth phase. A previous study showed that the production of the $\beta$-glucanase in B. subtilis was present during the lag phase of bacterial growth and reached its peak at $12 \mathrm{~h}$ of incubation (Dewi et al. 2016). Production of $\beta$-glucanase in the $B$. subtilis occurs in the supplementation of $0.3 \%$ chitin. Glucanolytic activity increased from day 1 to day 5 and remained constant until day 7 (Leelasuphakul et al. 2006). The peak of optimum activity was an indication of the presence of isoenzyme of $\beta$-glucanase of isolate W3.15 which started its activity in the following hours. These results also indicated that $\beta$ glucanase produced by $B$. subtilis W3.15 showed heterogeneity of enzyme form with different functional properties. Paenibacillus glycanilyticus FH11 produced isoenzymes of $\alpha$-1.3-glucanase (Agl-FH1 and Agl-FH2) that exhibit hydrolytic activity against the cell wall of the Schizophyllum commune mycelia (Suyotha et al. 2014).

Ammonium sulfate precipitation is widely used for enzyme purification produced by bacteria. Purified $\beta$ glucanase from isolate W3.15 exhibits higher specific activity than that of the culture filtrate, indicating that precipitation with ammonium sulfate in saturation of $60 \%$ (w/v) succeeded in removing other compounds and protein that retain enzyme activity. It is consistent with the previous report that the proper saturation of ammonium sulfate precipitation in $\beta$-glucanase purification is in the range of $40-60 \%$ (Xu et al. 2016). Several previous studies showed that purified enzyme derived from ammonium sulfate fraction had higher specific activity than its culture filtrate. Purified chitinase/chitosanase from B. cereus and Stenotrophomonas malthophilia using ammonium sulfate precipitation increase specific activity and enzyme recovery than the initial activity (Jankiewicz et al. 2012; Liang et al. 2014). Purified $\beta$-glucanase of $B$. subtilis W3.15 showed an appropriate activity in catalyzing $\beta$ glucan substrate under neutral conditions $(\mathrm{pH} 7)$ and in the temperature range of $70-80^{\circ} \mathrm{C}$.

The degree of acidity $(\mathrm{pH})$ and temperature are two essential factors affecting enzyme activity in catalyzing substrate reactions. Some enzymes have optimum activity under acid conditions and become unstable under alkaline conditions. The optimum enzyme activity for thermostable enzymes was at the temperature of above $80^{\circ} \mathrm{C}$, but the high temperature could lead to protein denaturation and significantly reduce enzyme activity for mesophilic enzymes. A study by Ferrer (2006) showed that $\beta$ glucanase from Cellulosimicrobium cellulans had an optimum $\mathrm{pH}$ in the range of 5.5 to 8 and a temperature of $70^{\circ} \mathrm{C}$. Moreover, the optimum enzyme activity of $\beta-1.3-$ 1.4-glucanase produced by $B$. subtilis 168 was reached at pH 6 and a temperature of $50{ }^{\circ} \mathrm{C}$ (Furtado et al. 2011). The optimum activity of chitinase was obtained in the $\mathrm{pH}$ range of 7-8 and temperature range of $30-40{ }^{\circ} \mathrm{C}$ (Kuddus and Ahmad 2013; Liang et al. 2014; Senol et al. 2014). The higher temperature on $\beta$-glucanase purification of isolate W3.15 might be related to the presence of a hydrophobic cluster or salt bridge of the enzyme. The effect of metal ions on $\beta$-glucanase of isolate W3.15 differed from that of Bacillus sp. CSB55 whose activity was increased in the presence of $\mathrm{Mn}^{2+}$ and unaltered by monovalent ion $\mathrm{Na}^{+}$and inhibitor EDTA (Regmi et al. 2020). 
Screening of lytic enzymes such as $\beta$-glucanase to control phytopathogenic fungi is carried out in in-vitro plate assay. Mycelial growth of $F$. oxysporum is significantly inhibited by cell culture and cell supernatant of B. subtilis W3.15. It indicated that hydrolytic enzymes, $\beta$-glucanase, and protease, in the bacterial cell and culture filtrate have an important role in damaging the mycelium of Fusarium. The role of the bacterial lytic enzyme is mainly in the degradation of the cell wall and hyphae, and inhibit hyphae elongation (Huang et al. 2012). The previous study showed that hydrolytic enzyme chitinase, pectinases, and xylanases of $B$. simplex exhibit antifungal activity against Fusarium spp. (Khan et al. 2018). Moreover, deformities of $F$. oxysporum colonies which are inhibited by bacterial cell and culture filtrate might be led to mycelial death as an effect of alteration of structural architect or lysis of mycelia (Kumar et al. 2012). It also reported that the growth inhibition of $R$. solani by $B$. subtilis SL-44 was caused by fracturing the mycelia and leaking of cell contents as an effect of surfactin, iturin, and fengycin in culture filtrate (Wu et al. 2019). Antifungal activity of B. subtilis W3.15 is also proved by its ability to reduce fungal biomass. This result is consistent with the reduction of $F$. udum biomass in co-culture treatment with native chitinolytic bacteria of pigeon pea (Cajanus cajan L.) (Dukare et al. 2020). Reduction in fungal biomass may cause by the secondary metabolites secreted by bacteria that inhibit the fungal growth (Moussa et al. 2020). Fungal biomass reduction is probably due to inhibition of the spore germination or hyphal lysis by metabolite produced by biocontrol bacteria (Chang et al. 2007). Therefore, it can be concluded that Bacillus subtilis W3.15 is a potential bacteria as a biocontrol agent for phytopathogenic fungi particularly $F$. oxysporum. However, further study and evaluation in another antifungal bioactive compound and several abilities in plant-growth-promoting traits to help the crops protect and increase crop yields is needed.

\section{ACKNOWLEDGEMENTS}

The authors are thankful to the Division of Microbiology and Division of Plant Science, IPB University, Bogor, Indonesia for providing the facilities for data collection. This research was funded by the Ministry of Research, Technology and Higher Education (now Ministry of Education and Culture), the Republic of Indonesia through the Master's Education Scholarships towards Doctorate for Excellence Scholars (PMDSU) scheme batch IV for the period year 2018-2022 to the promoter Dr. Nisa Rachmania Mubarik.

\section{REFERENCES}

Abo-Elyousr KAM, Mohamed HM. 2009. Biological control of fusarium wilt in tomato by plant growth-promoting yeasts and rhizobacteria. Plant Pathol J 25 (2): 199-204. DOI: 10.5423/PPJ.2009.25.2.199.

Alamri S, Hashem M, Mostafa YS. 2012. In vitro and in vivo biocontrol of soil-borne phytopathogenic fungi by certain bioagents and their possible mode of action. Biocontrol Sci 17 (4): 155-167. DOI: 10.4265/bio.17.155.
Amini J, Dzhalilov FS. 2010. The effects of fungicides on Fusarium oxysporum f. sp. lycopersici associated with fusarium wilt of tomato. J Plant Prot Res 50 (2): 172-178. DOI: 10.2478/v10045-010-0029-x.

Asha BM, Revathi M, Yadav A, Sakthivel N. 2012. Purification and characterization of a thermophilic cellulase from a novel cellulolytic strain, Paenibacillus barcinonensis. J Microbiol Biotechnol 22 (11): 1501-1509. DOI: 10.4014/jmb.1202.02013.

Awan ZA, Shoaib A. 2019. Combating early blight infection by employing Bacillus subtilis in combination with plant fertilizers. Curr Plant Biol 20: 100125. DOI: 10.1016/j.cpb.2019.100125.

Baibakova EV, Nefedjeva EE, Suska-Malawska M, Wilk M, Sevriukova GA, Zheltobriukhov VF. 2019. Modern fungicides: Mechanisms of action, fungal resistance and phytotoxic effects. Annu Res Rev Biol 32 (3): 1-16. DOI: 10.9734/arrb/2019/v32i330083.

Balhara M, Ruhil S, Dhankhar S, K. Chhillar A. 2011. bioactive compounds hold up- Bacillus amyloliquefaciens as a potent biocontrol agent. Nat Prod J 1 (1): 20-28.

Bradford MM. 1976. A rapid and sensitive method for the quantitation of microgram quantities of protein utilizing the principle of protein-dye binding. Anal Biochem 72 (1-2): 248-254. DOI: 10.1016/00032697(76)90527-3.

Chang WT, Chen YC, Jao CL. 2007. Antifungal activity and enhancement of plant growth by Bacillus cereus grown on shellfish chitin wastes. Bioresour Technol 98 (6): 1224-1230. DOI: 10.1016/j.biortech.2006.05.005.

Chasanah E, Dini IR, Mubarik NR. 2013. Characterization of PMP 0126Y cellulase enzyme from agar processing waste. JPB Perikan 8 (2): 103. DOI: 10.15578/jpbkp.v8i2.41. [Indonesian]

Chávez-Ramírez B, Kerber-Díaz JC, Acoltzi-Conde MC, Ibarra JA, Vásquez-Murrieta MS, Estrada-de los Santos P. 2020. Inhibition of Rhizoctonia solani RhCh-14 and Pythium ultimum PyFr-14 by Paenibacillus polymyxa NMA1017 and Burkholderia cenocepacia CACua-24: A proposal for biocontrol of phytopathogenic fungi. Microbiol Res 230: 126347. DOI: 10.1016/j.micres.2019.126347.

Chowdhury SP, Dietel K, Rändler M, Schmid M, Junge H, Borriss R, Hartmann A, Grosch R. 2013. Effects of Bacillus amyloliquefaciens FZB42 on lettuce growth and health under pathogen pressure and its impact on the rhizosphere bacterial community. PLoS One 8 (7): e68818. DOI: 10.1371/journal.pone.0068818.

Deng A, Wu J, Zhang Y, Zhang G, Wen T. 2010. Purification and characterization of a surfactant-stable high-alkaline protease from Bacillus sp. B001. Bioresour Technol 101 (18): 7100-7106. DOI: 10.1016/j.biortech.2010.03.130.

Dewi RTK, Mubarik NR, Suhartono MT. 2016. Medium optimization of $\beta$-glucanase production by Bacillus subtilis SAHA 32.6 used as biological control of oil palm pathogen. Emirates J Food Agric 28 (2): 116-125. DOI: 10.9755/ejfa.2015-05-195.

Dukare A, Paul S, Arambam A. 2020. Isolation and efficacy of native chitinolytic rhizobacteria for biocontrol activities against Fusarium wilt and plant growth promotion in pigeon pea (Cajanus cajan L.). Egypt J Biol Pest Control 30 (1): 56. DOI: 10.1186/s41938-02000256-7.

El-Bendary MA, Hamed HA, Moharam ME. 2016. Potential of Bacillus isolates as bio-control agents against some fungal phytopathogens. Biocatal Agric Biotechnol 5: 173-178. DOI: 10.1016/j.bcab.2016.02.001.

Elanchezhiyan K, Keerthana U, Nagendran K, Prabhukarthikeyan SR, Prabakar K, Raguchander T, Karthikeyan G. 2018. Multifaceted benefits of Bacillus amyloliquefaciens strain FBZ24 in the management of wilt disease in tomato caused by Fusarium oxysporum f. sp. lycopersici. Physiol Mol Plant Pathol 103: 92-101. DOI: 10.1016/j.pmpp.2018.05.008.

Falcão VCA, Ono MA, de Ávila Miguel T, Vizoni E, Hirooka EY, Ono EYS. 2011. Fusarium verticillioides: Evaluation of fumonisin production and effect of fungicides on in vitro inhibition of mycelial growth. Mycopathologia 171 (1): 77-84. DOI: 10.1007/s11046-0109339-9.

Ferrer P. 2006). Revisiting the Cellulosimicrobium cellulons yeast-lytic $\beta$ 1, 3-glucanases toolbox: A review. Microb Cell Fact 5: 10. DOI: 10.1186/1475-2859-5-10.

Furtado GP, Ribeiro LF, Santos CR, Tonoli CC, De Souza AR, Oliveira RR, Murakami MT, Ward RJ. 2011. Biochemical and structural characterization of a $\beta-1,3-1,4$-glucanase from Bacillus subtilis 168 . Process Biochem $4 \quad 6 \quad$ (5): 1202-1206. DOI: 10.1016/j.procbio.2011.01.037. 
Gomaa EZ. 2012. Chitinase production by Bacillus thuringiensis and Bacillus licheniformis: Their potential in antifungal biocontrol. J Microbiol 50 (1): 103-111. DOI: 10.1007/s12275-012-1343-y.

Haidar R, Roudet J, Bonnard O, Dufour MC, Corio-Costet MF, Fert M, Gautier T, Deschamps A, Fermaud M. 2016. Screening and modes of action of antagonistic bacteria to control the fungal pathogen Phaeomoniella chlamydospora involved in grapevine trunk diseases. Microbiol Res 192: 172-184. DOI: 10.1016/j.micres.2016.07.003.

Hendricks CW, Doyle JD, Hugley B. 1995. A new solid medium for enumerating cellulose-utilizing bacteria in soil. Appl Environ Microbiol 61 (5): 2016-2019. DOI: 10.1128/aem.61.5.20162019.1995

Huang X, Zhang N, Yong X, Yang X, Shen Q. 2012. Biocontrol of Rhizoctonia solani damping-off disease in cucumber with Bacillus pumilus SQR-N43. Microbiol Res 167 (3): 135-143. DOI: 10.1016/j.micres.2011.06.002.

Jankiewicz U, Brzezinska MS, Saks E. 2012. Identification and characterization of a chitinase of Stenotrophomonas maltophilia, a bacterium that is antagonistic towards fungal phytopathogens. J Biosci Bioeng 113 (1): 30-35. DOI: 10.1016/j.jbiosc.2011.08.023

Jiang CH, Liao MJ, Wang HK, Zheng MZ, Xu JJ, Guo JH. 2018. Bacillus velezensis, a potential and efficient biocontrol agent in control of pepper gray mold caused by Botrytis cinerea. Biol Control 126: 147157. DOI: 10.1016/j.biocontrol.2018.07.017.

Jiang CH, Yao XF, Mi DD, Li ZJ, Yang BY, Zheng Y, Qi YJ, Guo AH 2019. Comparative transcriptome analysis reveals the biocontrol mechanism of Bacillus velezensis F21 against fusarium wilt on watermelon. Front Microbiol 10: 1-17. DOI: 10.3389/fmicb.2019.00652

Karthik N, Binod P, Pandey A. 2015. Purification and characterisation of an acidic and antifungal chitinase produced by a Streptomyces sp. Bioresour Technol 188: 195-201. DOI: 10.1016/j.biortech.2015.03.006.

Khan MS, Gao J, Chen X, Zhang M, Yang F, Du Y, Moe TS, Munir I, Xue J, Zhang X. 2020. The endophytic bacteria Bacillus velezensis Lle-9, isolated from Lilium leucanthum, harbors antifungal activity and plant growth-promoting effects. $J$ Microbiol Biotechnol 30 (5): 668-680. DOI: 10.4014/jmb.1910.10021.

Khan N, Martínez-Hidalgo P, Ice TA, Maymon M, Humm EA, Nejat N, Sanders ER, Kaplan D, Hirsch AM. 2018. Antifungal activity of Bacillus species against Fusarium and analysis of the potential mechanisms used in biocontrol. Front Microbiol 9: 2363. DOI: 10.3389/fmicb.2018.02363.

Kim DS, Chi WJ, Hong SK. 2019. Molecular characterization of an endo$\beta$-1,4-glucanase, CelAJ93, from the recently isolated marine bacterium, Cellulophaga sp. J9-3. Appl Sci 9 (19): 4061. DOI: 10.3390/app9194061.

Kim YT, Monkhung S, Lee YS, Kim KY. 2019. Effects of Lysobacter antibioticus hs124, an effective biocontrol agent against Fusarium graminearum, on crown rot disease and growth promotion of wheat. Can J Microbiol 65 (12): 904-912. DOI: 10.1139/cjm-2019-0285.

Kuddus S, Ahmad IR. 2013. Isolation of novel chitinolytic bacteria and production optimization of extracellular chitinase. J Genet Eng Biotechnol 11 (1): 39-46. DOI: 10.1016/j.jgeb.2013.03.001.

Kumar P, Dubey RC, Maheshwari DK. 2012. Bacillus strains isolated from rhizosphere showed plant growth promoting and antagonistic activity against phytopathogens. Microbiol Res 167 (8): 493-499. DOI: 10.1016/j.micres.2012.05.002.

Leelasuphakul W, Sivanunsakul P, Phongpaichit S. 2006. Purification, characterization and synergistic activity of $\beta-1,3$-glucanase and antibiotic extract from an antagonistic Bacillus subtilis NSRS 89-24 against rice blast and sheath blight. Enzyme Microb Technol 38 (7): 990-997. DOI: 10.1016/j.enzmictec.2005.08.030.

Liang TW, Chen YY, Pan PS, Wang SL. 2014. Purification of chitinase/chitosanase from Bacillus cereus and discovery of an enzyme inhibitor. Int $\mathrm{J}$ Biol Macromol 63: 8-14. DOI: 10.1016/j.ijbiomac.2013.10.027.

Marchesi JR, Sato T, Weightman AJ, Martin TA, Fry JC, Hiom SJ, Wade WG (1998. Design and evaluation of useful bacterium-specific PCR primers that amplify genes coding for bacterial 16S rRNA. Appl Environ Microbiol 64 (2): 795-799. DOI: 10.1128/aem.64.2.795799.1998 .
Miller GL (1959. Use of dinitrosalicylic acid reagent for determination of reducing sugar. Anal Chem 31 (3): 426-428. DOI: 10.1021/ac60147a030.

Moussa M, Ebrahim W, Kalscheuer R, Liu Z, Proksch P. 2020. Co-culture of the bacterium Pseudomonas aeruginosa with the fungus Fusarium tricinctum induces bacterial antifungal and quorum sensing signaling molecules. Phytochem Lett 36: 37-41. DOI: 10.1016/j.phytol.2020.01.013.

Moyes RB, Reynolds J, Breakwell DP. 2009. Differential staining of bacteria: Gram stain. Curr Protoc Microbiol 15 (1): A.3C.1-A.3C.8. DOI: 10.1002/9780471729259.mca03cs15.

Mutturi S, Ike M, Yamagishi K, Tokuyasu K. 2020. Isolation, characterization, and application of thermotolerant Streptomyces sp. $\mathrm{K} 5$ for efficient conversion of cellobiose to chitinase using pulsefeeding strategy. Process Biochem 94: 58-65. DOI: 10.1016/j.procbio.2020.04.009

Nel B, Steinberg C, Labuschagne N, Viljoen A. 2007. Evaluation of fungicides and sterilants for potential application in the management of Fusarium wilt of banana. Crop Prot 26 (4): 697-705. DOI: 10.1016/j.cropro.2006.06.008.

Regmi S, Choi YS, Kim YK, Khan MM, Lee SH, Choi YH, Cho SS, Jin YY, Yoo JC, Suh JW. 2020. Industrial attributes of $\beta$-glucanase produced by Bacillus sp. CSB55 and its potential application as bioindustrial catalyst. Bioprocess Biosyst Eng 43 (2): 249-259. DOI: 10.1007/s00449-019-02221-7.

Roy A, Mahata D, Paul D, Korpole S, Franco OL, Mandal SM. 2013. Purification, biochemical characterization and self-assembled structure of a fengycin-like antifungal peptide from Bacillus thuringiensis strain SM1. Front Microbiol 4: 332. DOI: 10.3389/fmicb.2013.00332.

Schoffelmeer E, Klis F, Sietsma J, Cornelissen B. 1999. The cell wall of Fusarium oxysporum. Fungal Genet Biol 27 (2-3): 275-82. DOI: 10.1006/fgbi.1999.1153.

Senol M, Nadaroglu H, Dikbas N, Kotan R. 2014. Purification of chitinase enzymes from Bacillus subtilis bacteria TV-125, investigation of kinetic properties and antifungal activity against Fusarium culmorum. Ann Clin Microbiol Antimicrob 13 (1): 1-7. DOI: 10.1186/s12941014-0035-3.

Suárez-Estrella F, Vargas-García C, López MJ, Capel C, Moreno J. 2007. Antagonistic activity of bacteria and fungi from horticultural compost against Fusarium oxysporum f. sp. melonis. Crop Prot 26 (1): 46-53. DOI: 10.1016/j.cropro.2006.04.003.

Suyotha W, Yano S, Itoh T, Fujimoto H, Hibi T, Tachiki T, Wakayama M. 2014. Characterization of $\alpha-1,3$-glucanase isozyme from Paenibacillus glycanilyticus FH11 in a new subgroup of family $87 \alpha-$ 1,3-glucanase. J Biosci Bioeng 118 (4): 378-385. DOI: 10.1016/j.jbiosc.2014.03.008.

Trinh THT, Wang SL, Nguyen VB, Tran MD, Doan CT, Vo TPK, Huynh Q V, Nguyen AD. 2019. A potent antifungal rhizobacteria Bacillus velezensis RB.DS29 isolated from black pepper (Piper nigrum L.). Res Chem Intermed 45(11): 5309-5323. DOI: 10.1007/s11164-01903971-5.

Wikandari PR, Suparmo S, Marsono Y, Rahayu ES. 2012. Characterization of proteolytic lactic acid bacteria on bekasam. J Natur Indones 14 (1): 120. DOI: 10.31258/jnat.14.1.120-125. [Indonesian]

Wu Z, Huang Y, Li Y, Dong J, Liu X, Li C. 2019. Biocontrol of Rhizoctonia solani via induction of the defense mechanism and antimicrobial compounds produced by Bacillus subtilis SL-44 on pepper (Capsicum annuum L.). Front Microbiol 10: 02676. DOI: 10.3389/fmicb.2019.02676.

Xu T, Zhu T, Li S. 2016. $\beta$-1,3-1,4-glucanase gene from Bacillus velezensis zj20 exerts antifungal effect on plant pathogenic fungi. World J Microbiol Biotechnol 32 (2): 1-9. DOI: 10.1007/s11274-0151985-0.

Yu WQ, Zheng GP, Qiu DW, Yan FC, Liu WZ, Liu WX. 2019. Paenibacillus terrae NK3-4: A potential biocontrol agent that produces $\beta-1,3$-glucanase. Biol Control 129: 92-101. DOI: 10.1016/j.biocontrol.2018.09.019.

Zhang Y, Xu J, Dong F, Liu X, Wu X, Zheng Y. 2014. Response of microbial community to a new fungicide fluopyram in the silty-loam agricultural soil. Ecotoxicol Environ Saf 108: 273-280. DOI: 10.1016/j.ecoenv.2014.07.018. 